\title{
Study of a high efficiency residential split water-cooled air conditioner
}

\author{
S.S. Hu, B.J. Huang * \\ Department of Mechanical Engineering, National Taiwan University, Taipei 106, Taiwan
}

Received 20 August 2004; accepted 20 November 2004

Available online 29 January 2005

\begin{abstract}
This paper presents an experimental investigation of a high-efficiency split residential water-cooled air conditioner that utilizes cellulose pad as the filling material of the cooling tower. The cooling tower performance is improved due to good water wettability of the cellulose pad that causes a uniform water film over the entire surface of the pads and a perfect contact between water and cooling air. The cooling tower is integrated with the condensing unit of the Rankine-cycle in structure design to form an integral-type outdoor unit. The heat and mass transfer characteristics of the cellulose pads is first studied and the results are used for the design of the cooling tower. A prototype with $3.52 \mathrm{~kW}$ cooling capacity was constructed and tested in the present study. The experimental results show the coefficient of performance (COP) reaches 3.45 at wet-bulb temperature $27^{\circ} \mathrm{C}$, dry-bulb temperature $35^{\circ} \mathrm{C}$, air velocity $1.7 \mathrm{~m} / \mathrm{s}$, water flow rate $5.1 \mathrm{l} / \mathrm{min}$, and that is higher than the standard value (2.96) of those conventional residential split air conditioners. (C) 2004 Elsevier Ltd. All rights reserved.
\end{abstract}

\section{Introduction}

The Taiwan Government intends to reduce greenhouse gas emissions from power plant and lower the energy consumption of residential sector by increasing the COP of the residential air

\footnotetext{
* Corresponding author. Tel.: +886 22363 4790/2362 4790; fax: +886 223640549.

E-mail address: bjhuang@seed.net.tw (B.J. Huang).
} 


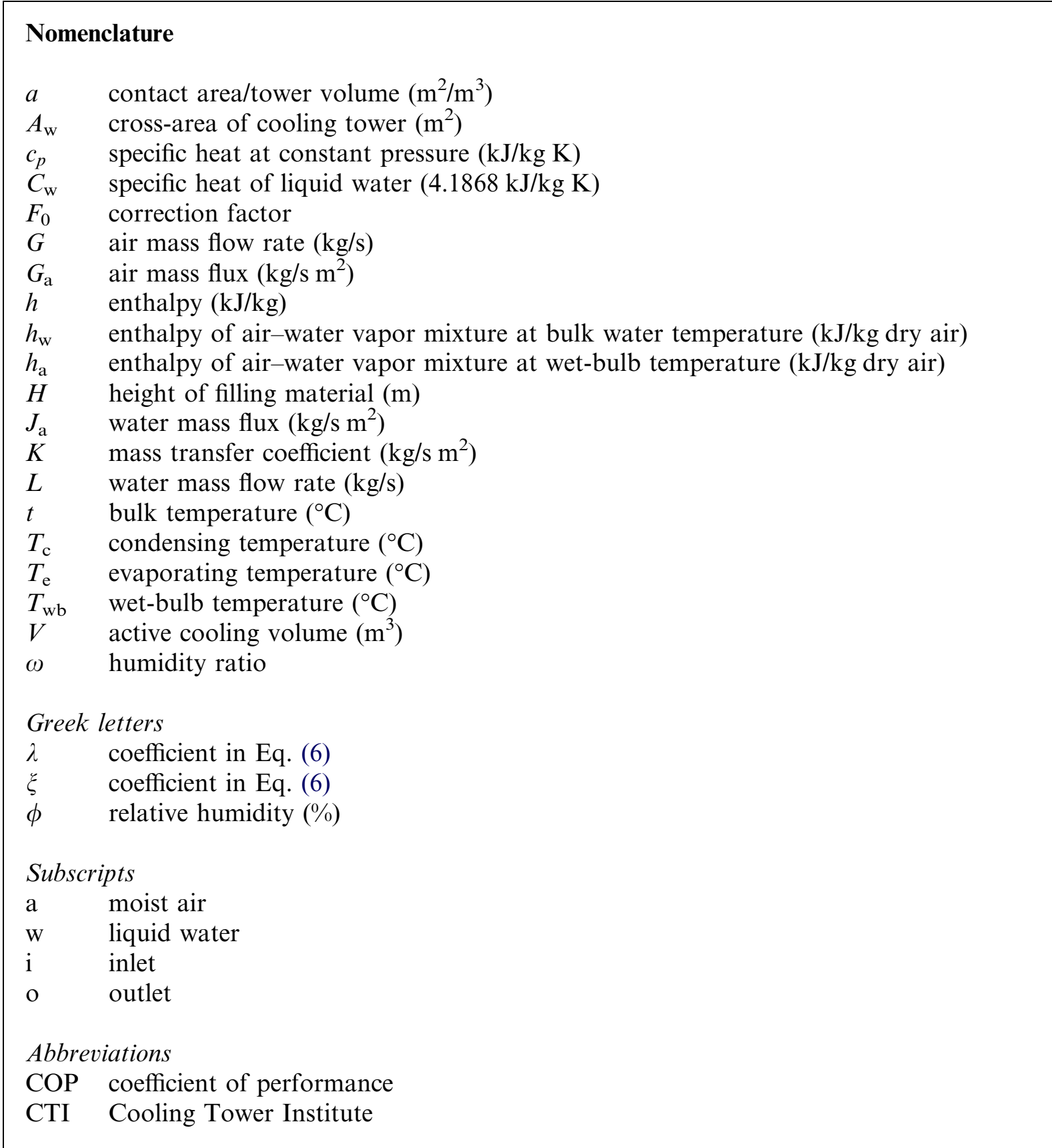

conditioners by $20 \%$, that is, from 2.96 at the present regulation to 3.45 in the next 3 years. Normally, the COP can be improved by lowering the compressor power consumption, increasing the cooling and heat rejection capacity, decreasing the refrigerant pressure lose, or reducing the pressure difference between the condenser and evaporator. Reducing the pressure difference between 
the condenser and evaporator is the fruitful one in comparison with those mentioned above. While the evaporating temperature is kept constant, lowering the condensing temperature results in the reduction of pressure difference.

In general, there are three kinds of condensers using in air conditioning system: air-cooled, evaporatively-cooled, and water-cooled. Condensers used in conventional small tonnage residential split air conditioners are mostly air-cooled. Their performance depends on the heat transfer between the coils and the airflow. In this regard, air-cooled condensers need a high airflow rate for improved performance, and thus sometimes results in noise problem.

Evaporative cooled condensers include a spray of water falling onto the condenser tubes as air is simultaneously blown over the tubes. The water that is not evaporated then drains to the bottom of the condenser unit and is pumped back up to the sprayers by a water pump. Cooling is accomplished by the evaporation of the water into the air-stream. However, the evaporativelycooled condensers are complicated since the surface of the condenser tubes needs to be covered with a layer of fiber to maintain a perfect contact between air and water. It is thus expensive and difficult to maintain for small tonnage residential split-type air conditioners.

Hwang [1] carried out a $7.4 \mathrm{~kW}$ residential split heat pump system utilizing an innovative design of evaporatively-cooled condenser. The condenser was $1 \mathrm{~m}$ wide, $0.66 \mathrm{~m}$ long and $0.66 \mathrm{~m}$ high. The heat to be removed from condenser was taken place in a cooling water tank where the condenser tubes were immersed. The heated water in the tank was lifted by the rotating disks which partly immersed in the water and then cooled by the cooling air flow. The test results showed that COP was increased by $11.1-21.6 \%$ as compared to the air-cooled condenser. However, the size of Hwang's system was too large, heavy and complicate for residential application.

The performance of a water-cooled condenser depends on the heat transfer between the refrigerant tubes and water flow. Water-cooled condensers not only have a higher heat transfer coefficient than air-cooled condensers but also have a simpler configuration than evaporative cooled condensers. Groseclose [2] also showed that the cost of the water-cooled condensers with cooling towers and the evaporative cooling condensers are almost the same. Nevertheless, the conventional water-cooled condensers involve a cooling tower, which also imply a larger installation space and extra power for fan and pump.

In the present study, we intend to develop a water-cooled technology for residential split-type air conditioner to have higher COP than the standard value of 2.96 . The performance of the water-cooled condenser is elevated by improving the air-water cooling design using a special filling material. A cross-flow type cooling tower is taken to compromise with the installation space.

The selection of the filling material of the cooling tower is very crucial. Most of the conventional cooling tower utilizes plastic packing as a filling material and the wettability of water on the plastic surface is not perfect due to the surface tension phenomenon. The contact surface area between the air and water streams in the condenser is thus not the total surface area of the packing materials. Therefore, we adopt the cellulose pad as the filling material to increase the contact area between water and air. Mainly, the cellulose pad, which is in cellulose bound cardboard structure, is applied to evaporative air cooling system. That design is of cross-fluted type and has a capillary force to cause a uniform water film over the pads. In other words, the capillary force makes the cellulose pads not only a contact area but also a water dispersing device on the surface of the filling material without any power consumption or any modification. Hence, the contact between water and cooling air for water evaporating process is perfect [3]. The average life expectancy 
of the cellulose pads is of the order of five years. With clean water, it may last up to more than 10 years [4]. The mineral deposits and dirt can be flushed from the surface of the pad due to the steeper angle of cellulose pads unequal flute design. The cellulose pad is inexpensive and can be replaced periodically if necessary.

Goswami [5] designed an $8.8 \mathrm{~kW}$ residential air conditioner retrofitted with an air-cooled system using a cellulose pad evaporative cooling device for air. Air was pre-cooled before entering the condenser by passing through the wetted cellulose pads to improve the efficiency of air-cooled condenser. An increase of the system performance by approximately $22 \%$ was achieved. The electric energy savings was $20 \%$ and the payback time for the retrofit in shorter less than two years. The condenser of the air conditioner designed by Goswami [5] is basically an air-cooled type since the cooling medium is air. The evaporative cooling was used to pre-cooling the incoming air stream.

Here we develop a simple water-cooled air conditioner utilizing a cooling tower with cellulose pad filling material to cool the water for condensing operation. The present system comprises a Rankine-cycle device and a cooling tower that is constructed in two parts: an indoor unit and an outdoor unit, as shown in Fig. 1. The indoor unit includes an evaporator with a fan coil and a capillary tube. The outdoor unit includes a fan, a water sprayer, a cooling tower using cellulose pad as the filling material, a water tank, a water pump, a water-cooled condenser and a

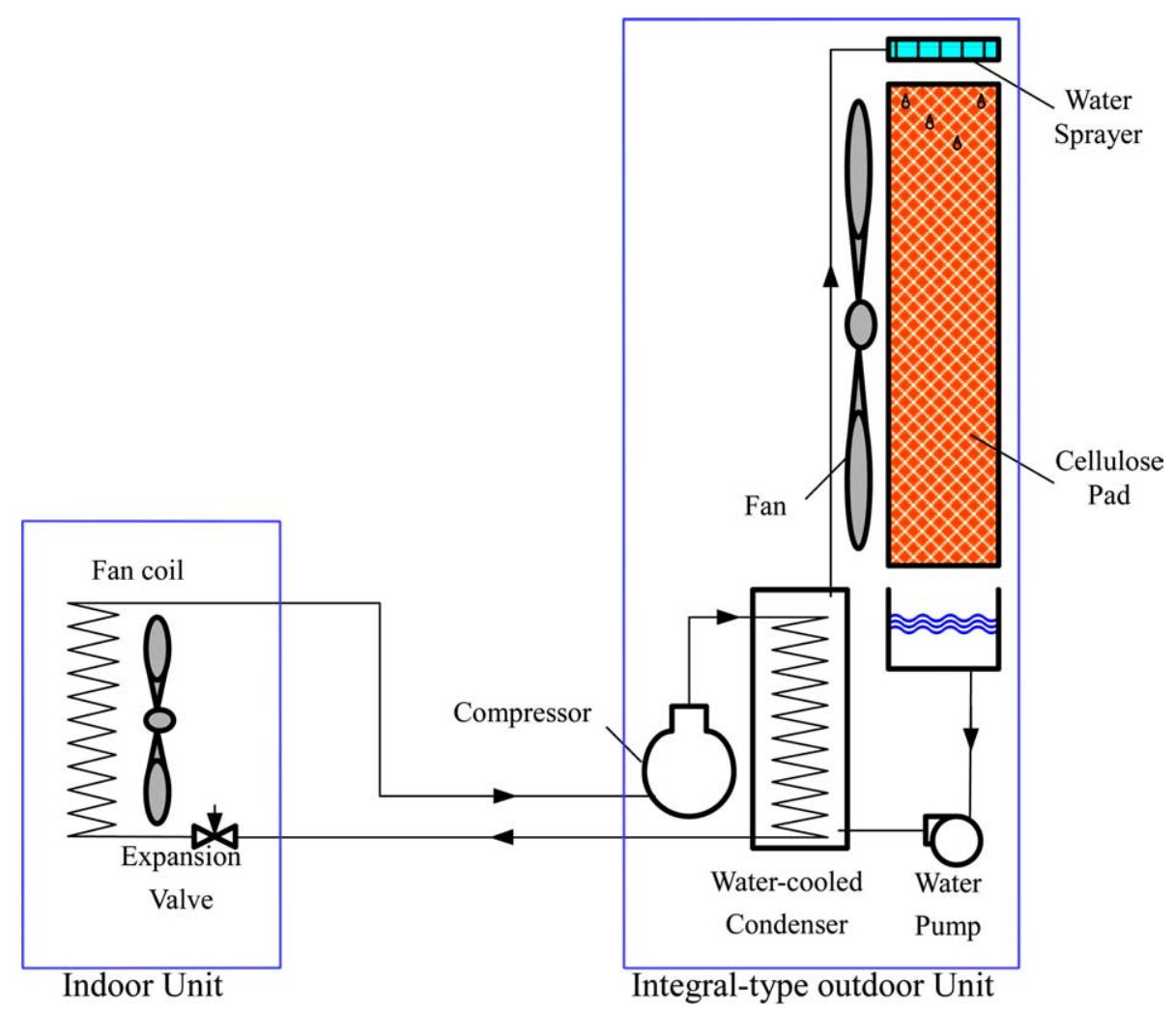

Fig. 1. The residential split water-cooled air conditioner. 
compressor. All the components of the outdoor unit are designed in integral-type to reduce the installation space.

The condenser of the Rankine-cycle is cooled by water. The water is sprayed through the water sprayer over the cellulose pads. A large contact surface area between water and air is provided to reject the heat to atmosphere through the water evaporating process. After heat is removed, the cooled water is collected in the water tank below the cellulose pad and pumped back by water pump to the condenser. The cross-flow type cooling tower with cellulose pad filling material is integrated with the Rankine-cycle unit in structure design, as shown schematically in Fig. 1.

The present investigation was conducted to demonstrate the feasibility of the above-mentioned residential split-type air conditioner utilizing the cross-flow cooling tower whose filling material is cellulose pads. The heat and mass transfer characteristics of the cellulose pads is first studied experimentally. The results are used in the design of a cooling tower for a prototype of air conditioner. The prototype was then constructed and tested for verification.

\section{Study of the heat and mass transfer characteristics of the cellulose pads}

The performance of a cooling tower depends on the filling material (size, shape, material content), water spray design and flow rates of water and air. Many studies experimenting with various filling materials on the heat and mass transfer characteristics have been carried out [6-10]. The basic theory of the cooling tower is well known. Dowdy [11] studied the fundamental heat and mass transfer phenomenon for the cooling of air using cellulose pads with cross-sectional area $1 \mathrm{ft} \times 1 \mathrm{ft}(30.5 \mathrm{~cm} \times 30.5 \mathrm{~cm})$ and thickness $2-12$ in. $(5.1-30.5 \mathrm{~cm})$. At fixed wet-bulb temperature $18{ }^{\circ} \mathrm{C}$, the heat and mass transfer correlations in different thickness were derived. However, his correlations primarily dealt with evaporative-cooling application where the water flow rate was small and provided merely to moisten the contact area for water evaporation. To date, no studies have been carried out to investigate the cooling of water utilizing the cellulose pads. Because Dowdy's results are not applicable to the design of the present water cooling tower, we present a first experimental study for investigating the heat and mass transfer characteristics of water cooling process in the cross-flow cooling tower using cellulose pads as the filling material.

\subsection{Testing equipment of cellulose pads}

The experimental setup of the system for testing the heat and mass transfer of cellulose pads is shown in Fig. 2.

An open wind tunnel with air flow rate control is used. The cellulose pad is installed in the test section with a water spray device and a water circulating system. The water flow is regulated by a ball valve and heated by a $5-\mathrm{kW}$ electrical heater installed in the water tank. The water temperature is controlled by a PID controller to simulate the inlet water condition of a cooling tower. The specifications of the experimental device are listed in Table 1 . The dimension of the cellulose pad specimen for the experiment is $0.3 \mathrm{~m} \times 0.3 \mathrm{~m} \times 0.15 \mathrm{~m}$ that can be treated as a fundamental cell unit in the design of the cooling tower.

As shown in Fig. 2, the test section contains six temperature measuring points including dryand wet-bulb temperatures in both front and rear test sections, and two water temperature points 


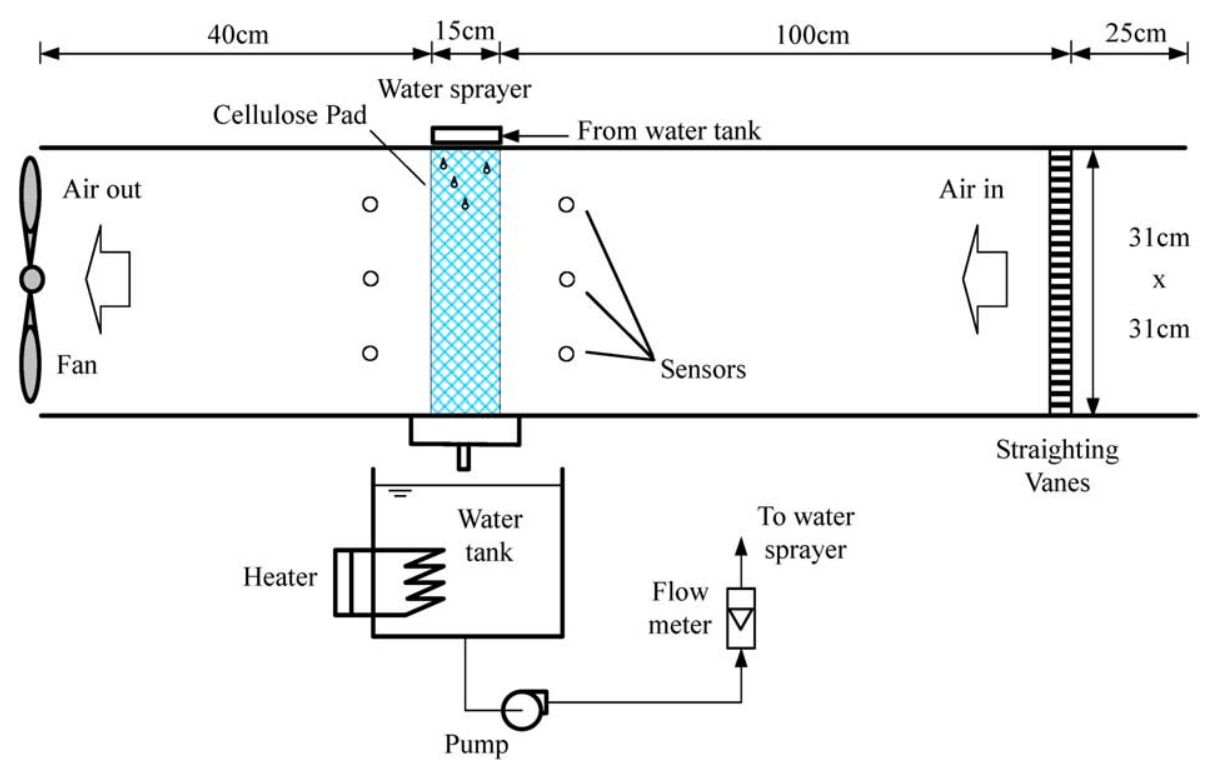

Fig. 2. Cellulose pad test system.

Table 1

Specifications of the wind tunnel test system

\begin{tabular}{ll}
\hline Component & Specification \\
\hline Fan & $180 \mathrm{~W}, 1590 \mathrm{rpm}, \max$ air flux $25 \mathrm{~m}^{3} / \mathrm{min}$ \\
Water pump & $20 \mathrm{~W}, \max$ head $2 \mathrm{~m}$, max flow rate $201 / \mathrm{min}$ \\
Cellulose pad specimen & $0.3 \mathrm{~m} \times 0.3 \mathrm{~m} \times 0.15 \mathrm{~m}$ \\
Wind tunnel & $0.31 \mathrm{~m} \times 0.31 \mathrm{~m} \times 1.8 \mathrm{~m}$ \\
\hline
\end{tabular}

at the inlet and outlet of the pad. All the temperature points have uncertainty of $\pm 0.7^{\circ} \mathrm{C}$. Water mass flow rate $(L)$ is measured within $\pm 4 \%$ uncertainty. Air mass flow rate $(G)$ is determined from the energy and mass balance using the measured data according to Eq. (1) and thus have $\pm 4.9 \%$ uncertainty.

$$
G=\left[L_{\mathrm{i}} \cdot\left(c_{p} t_{\mathrm{wi}}-c_{p} t_{\mathrm{wo}}\right) /\left(h_{\mathrm{ao}}-h_{\mathrm{ai}}\right)\right] /\left[1-\left(c_{p} t_{\mathrm{wo}}\left(\omega_{\mathrm{o}}-\omega_{\mathrm{i}}\right)\right)\right]
$$

where $L_{\mathrm{i}}$ is the inlet water mass flow rate, $c_{p}$ is the specific heat of water at constant pressure, $t_{\mathrm{wi}}$ and $t_{\mathrm{wo}}$ represent inlet and outlet water temperature, $h_{\mathrm{ai}}$ and $h_{\mathrm{ao}}$ represent the enthalpy of inlet and outlet air $\omega_{\mathrm{i}}$ and $\omega_{\mathrm{o}}$ represent the absolute humidity of inlet and outlet air streams.

\subsection{Test results for the cell of cellulose pads}

The heat and mass transfer characteristics of the fundamental cell unit of the cellulose pad can be described by the cooling tower characteristic parameter, $\mathrm{KaVlL}$, that is derived for counterflow cooling tower and is defined in Eq. (2) [12]. 


$$
\frac{K a V}{L}=C_{\mathrm{w}} \int_{t_{\mathrm{w}_{\mathrm{o}}}}^{t_{\mathrm{w}_{\mathrm{i}}}} \frac{\mathrm{d} t_{\mathrm{w}}}{h_{\mathrm{w}}-h_{\mathrm{a}}}
$$

where $K$ is the mass transfer coefficient, $a$ is the ratio of contact area to tower volume, $V$ is the active cooling volume, $L$ is the water mass flow rate, $C_{\mathrm{w}}$ is the specific heat of liquid water, $t_{\mathrm{w}}$ is the liquid water bulk temperature, $h_{\mathrm{w}}$ is the enthalpy of air-water vapor mixture, $h_{\mathrm{a}}$ is the enthalpy of air-water vapor mixture at wet-bulb temperature.

The integral of Eq. (2) is related to the inlet condition of air, inlet temperature of water and the water to air flowrate ratio. Cooling Tower Institute [13] suggested using the Four-Point Tchebycheff Function Evaluation to calculate the integration numerically.

$$
\frac{K a V}{L}=C_{\mathrm{w}} \int_{t_{\mathrm{w}_{\mathrm{o}}}}^{t_{\mathrm{w}_{\mathrm{i}}}} \frac{\mathrm{d} t_{\mathrm{w}}}{h_{\mathrm{w}}-h_{\mathrm{a}}} \cong \frac{t_{\mathrm{w}_{\mathrm{i}}}-t_{\mathrm{w}_{\mathrm{o}}}}{4}\left[\frac{1}{\Delta h_{1}}+\frac{1}{\Delta h_{2}}+\frac{1}{\Delta h_{3}}+\frac{1}{\Delta h_{4}}\right]
$$

where

$$
\begin{array}{ll}
\Delta h_{1}=\text { value of }\left(h_{\mathrm{w}}-h_{\mathrm{a}}\right) & \text { at } t_{1}=t_{\mathrm{w}_{\mathrm{o}}}+0.1\left(t_{\mathrm{w}_{\mathrm{i}}}-t_{\mathrm{w}_{\mathrm{o}}}\right) \quad \text { and } \quad h_{\mathrm{a}_{1}}=h_{\mathrm{a}_{i}}+0.1 L / G\left(t_{\mathrm{w}_{\mathrm{i}}}-t_{\mathrm{w}_{\mathrm{o}}}\right) \\
\Delta h_{2}=\text { value of }\left(h_{\mathrm{w}}-h_{\mathrm{a}}\right) & \text { at } t_{2}=t_{\mathrm{w}_{\mathrm{o}}}+0.4\left(t_{\mathrm{w}_{\mathrm{i}}}-t_{\mathrm{w}_{\mathrm{o}}}\right) \quad \text { and } \quad h_{\mathrm{a}_{2}}=h_{\mathrm{a}_{\mathrm{i}}}+0.4 L / G\left(t_{\mathrm{w}_{\mathrm{i}}}-t_{\mathrm{w}_{\mathrm{o}}}\right) \\
\Delta h_{3}=\text { value of }\left(h_{\mathrm{w}}-h_{\mathrm{a}}\right) & \text { at } t_{3}=t_{\mathrm{w}_{\mathrm{i}}}-0.4\left(t_{\mathrm{w}_{\mathrm{i}}}-t_{\mathrm{w}_{\mathrm{o}}}\right) \quad \text { and } \quad h_{\mathrm{a}_{3}}=h_{\mathrm{a}_{\mathrm{o}}}-0.4 L / G\left(t_{\mathrm{w}_{\mathrm{i}}}-t_{\mathrm{w}_{\mathrm{o}}}\right) \\
\Delta h_{4}=\text { value of }\left(h_{\mathrm{w}}-h_{\mathrm{a}}\right) & \text { at } t_{4}=t_{\mathrm{w}_{\mathrm{i}}}-0.1\left(t_{\mathrm{w}_{\mathrm{i}}}-t_{\mathrm{w}_{\mathrm{o}}}\right) \quad \text { and } \quad h_{\mathrm{a}_{4}}=h_{\mathrm{a}_{\mathrm{o}}}-0.1 L / G\left(t_{\mathrm{w}_{\mathrm{i}}}-t_{\mathrm{w}_{\mathrm{o}}}\right)
\end{array}
$$

As is well known, a correction factor $\left(F_{0}\right)$, which related to the arrangements of surface and flow and heat exchangers, is introduced to the performance of a cross-flow cooling tower when using the counter-flow theory. Therefore, Eq. (2) can be adopted in the cross-flow cooling tower after a correction factor was decided [14]. Fujita and Tezuka [15] derived a simple relation using the following definitions:

$$
\begin{aligned}
& (K a V / L)_{\text {Crossflow }}=\frac{(K a V / L)_{\text {Counterflow }}}{F_{0}} \\
& F_{0}=1-0.106\left(1-S_{0}\right)^{3.5}
\end{aligned}
$$

where

$$
S_{0}=\frac{\left(h_{\mathrm{wo}}-h_{\mathrm{ao}}\right)}{\left(h_{\mathrm{wi}}-h_{\mathrm{ai}}\right)}
$$

$h_{\mathrm{ai}}$ and $h_{\mathrm{ao}}$ represent the enthalpy of inlet and outlet air, $h_{\mathrm{wi}}$ and $h_{\mathrm{wo}}$ represent the enthalpy of inlet and outlet water.

According to Mohiuddin [9], a heat and mass transfer correlation, Eq. (7), holds for the cooling tower operation.

$$
\frac{K a}{J_{\mathrm{a}}}=\xi\left[\frac{J_{\mathrm{a}}}{G_{\mathrm{a}}}\right]^{-\lambda}
$$


where $J_{\mathrm{a}}$ and $G_{\mathrm{a}}$ are the water and air mass flux; $\xi$ and $\lambda$ are the characteristic parameters of the selected filling material that can be determined experimentally. Knowing the values of $J_{\mathrm{a}} / G_{\mathrm{a}}, \lambda$ and $\xi$, the value of $K a / J_{\mathrm{a}}$ can be calculated.

The experiment was carried out in the present study to determine the values of $\xi$ and $\lambda$ of the cellulose pads. The fundamental cell unit was tested at steady state within the operating range of wet-bulb temperature from 25.5 to $28.5^{\circ} \mathrm{C}$, relative humidity from $70 \%$ to $90 \%$, air velocity from 1.08 to $2.02 \mathrm{~m} / \mathrm{s}$, water flow rate from 4 to $61 / \mathrm{min}$ and the parameter $J_{\mathrm{a}} / G_{\mathrm{a}}$ from 0.5 to 2 .

The correction factor, $F_{0}$, is calculated by Eqs. (5) and (6) for the fundamental cell unit and it is near unity as shown in Fig. 3. This implies that the $K a V / L$ values for counter-flow and cross-flow are approximately the same.

The $K a V / L$ values of the fundamental cell unit at various operating conditions are calculated using the measured data and Eq. (3).

Note that $\frac{K a V}{L}=\frac{K a A_{\mathrm{w}} H}{L}=\frac{K a H}{L / A_{\mathrm{w}}}=\frac{K a H}{J_{\mathrm{a}}}$, and $K a / J_{\mathrm{a}}$ thus can be obtained. Consequently, the correlation likewise Eq. (7) is given by the following:

$$
\frac{K a}{J_{\mathrm{a}}}=2.2899\left[\frac{J_{\mathrm{a}}}{G_{\mathrm{a}}}\right]^{-0.3389}
$$

As shown in Fig. 4, Eq. (8) is within $\pm 5 \%$ error. This can be incorporated into the design of cooling tower with multiple fundamental cell units.

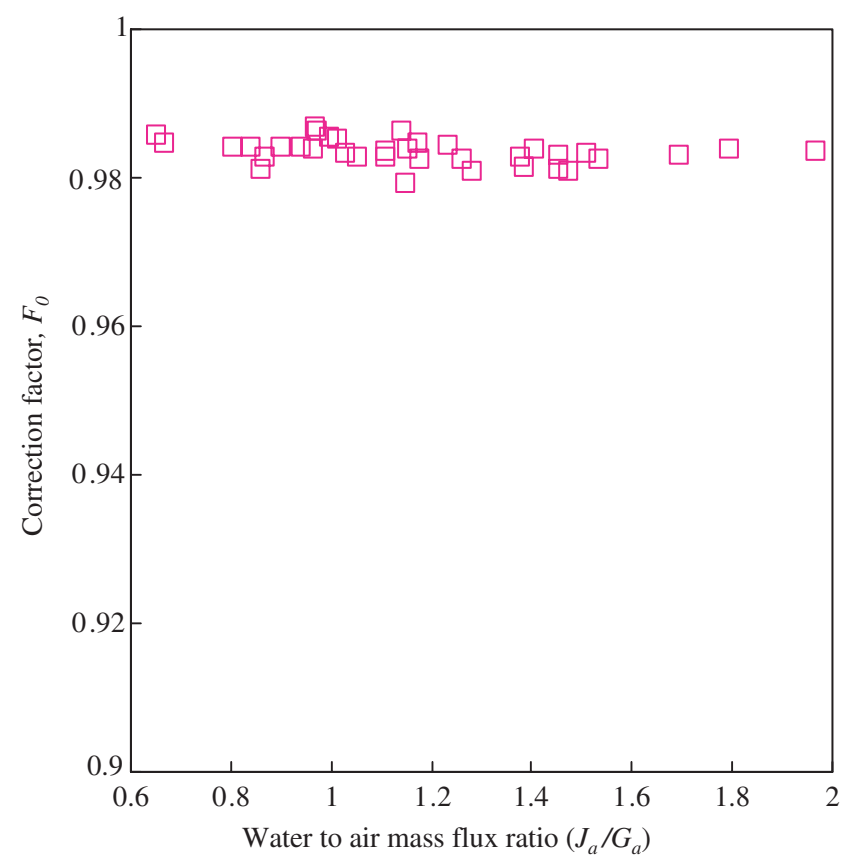

Fig. 3. Correction factor in different water to air mass flux ratio. 


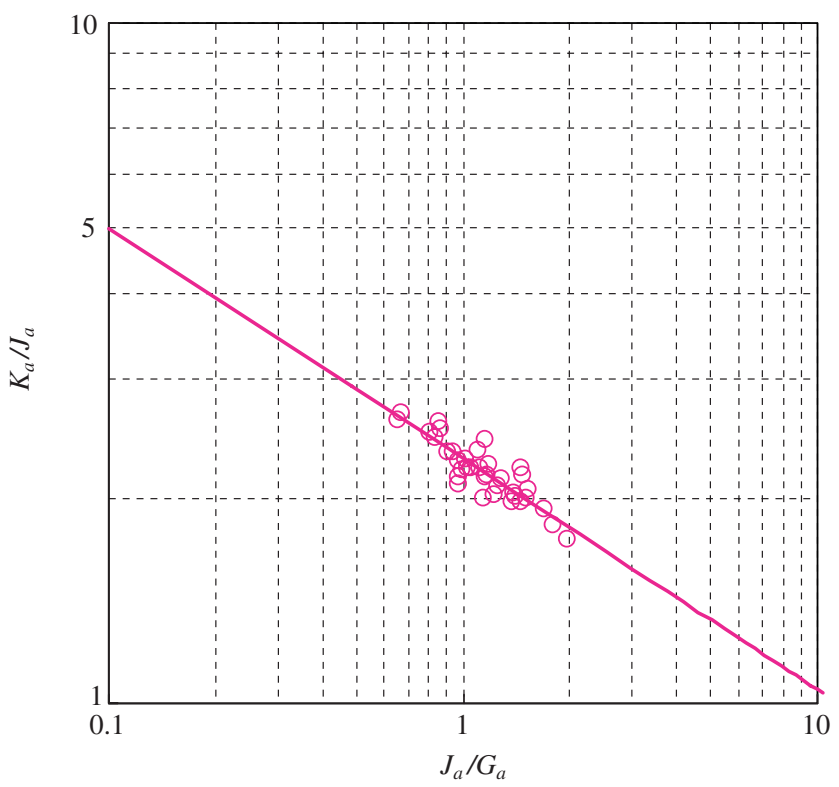

Fig. 4. Correlation of $K_{\mathrm{a}} / L_{\mathrm{a}}$.

\section{Experimental verification of a high-performance air conditioner}

\subsection{Prototype design}

A prototype following the process of Fig. 1 is designed to study the feasibility of the cross-flow cooling tower using cellulose pads as the filling material. The prototype is a residential split airconditioner that has a rated cooling capacity $3.52 \mathrm{~kW}$, power consumption $1.116 \mathrm{~kW}$ and a condenser capacity $4.64 \mathrm{~kW}$.

The refrigeration system is composed of the basic components of a Rankine-cycle system: a rotary R22 compressor, a water-cooled condenser, an evaporator, a capillary tube, an accumulator, and a separator. Condenser and evaporator are plate-type heat exchangers. The basic specifications of the refrigeration system are described in Table 2.

Table 2

The basic specifications of the Rankine-cycle unit

\begin{tabular}{ll}
\hline Component & Specification \\
\hline Compressor & R22, 1180 W/220 V, 20.7 cc/rev. \\
& Cooling capacity $3.46 \mathrm{~kW}$ \\
Condenser & Plate type, max transfer rate $7 \mathrm{~kW}$ \\
& Heat transfer area $0.975 \mathrm{~m}^{2}$ \\
Evaporator & Plate type, max transfer rate $5 \mathrm{~kW}$ \\
& Heat transfer area $0.72 \mathrm{~m}^{2}$ \\
\hline
\end{tabular}


A cooling tower specification usually includes water and air flow rate, cooling capacity range, approach and wet-bulb temperature. These conditions should be selected on the basis of the temperature at which the heat is to be removed from the condenser, and the wet-bulb temperature at which the cooling tower rejects the heat to the atmosphere.

A common rule to select a wet-bulb temperature, which varies with the local climate, is that will not be equaled or exceeded $3-5 \%$ of the time in an average operation months. On the basis of the 2001-2002 meteorological data from Taiwan Central Weather Bureau, as shown in Table 3, the average wet-bulb temperature ranges from $23.2^{\circ} \mathrm{C}$ to $25.8^{\circ} \mathrm{C}$ in summer. Hence, the wet-bulb temperature $27^{\circ} \mathrm{C}$ is reasonable as the baseline point for cooling tower design.

In regard to the power assumption of water pump, as small as possible, a $13 \mathrm{~W}$ water pump was selected to provide water flow rate around 4-61/min. Thus, the water temperature drop (water cooling range) in the cooling tower will be in the range $12-18{ }^{\circ} \mathrm{C}$. For illustration, assuming that the cooling tower temperature approach (cooling tower outlet water temperature minus wet-bulb temperature) is $1{ }^{\circ} \mathrm{C}$, the cooling tower outlet water temperature will be $27+1=28{ }^{\circ} \mathrm{C}$ and the possible inlet water temperature of the cooling tower will be $40-46^{\circ} \mathrm{C}$ for the cooling range $12-18^{\circ} \mathrm{C}$ at water flow rate $4-61 / \mathrm{min}$. This means the possible condensing temperature of the Rankine-cycle will be in the range $44-50{ }^{\circ} \mathrm{C}$ for the temperature gap $4{ }^{\circ} \mathrm{C}$ between the condensing temperature and inlet water temperature of the cooling tower.

In the design of the cooling tower, the $K a V / L$ values are evaluated from Eq. (3) for different cooling tower temperature approaches, by substituting the average value of the possible inlet water temperature of the cooling tower $43{ }^{\circ} \mathrm{C}$, average water cooling range $14.5-15.5^{\circ} \mathrm{C}$ at cooling tower temperature approach $0.5-1.5^{\circ} \mathrm{C}$, and inlet air condition at $T_{\mathrm{wb}}=27^{\circ} \mathrm{C}$ in different $J_{\mathrm{a}} / G_{\mathrm{a}}$. The variation of $\mathrm{KaVlL}$ values with $J_{\mathrm{a}} / G_{\mathrm{a}}$ is shown in Fig. 5 which represents the relation of Eq. (3).

The cooling tower height $H$ can be determined by using multiple fundamental cell units, Eq. (8), which can be expressed as Eq. (9).

$$
\frac{K a V}{L}=2.2899 H\left[\frac{J_{\mathrm{a}}}{G_{\mathrm{a}}}\right]^{-0.3389}
$$

At $H=30 \mathrm{~cm}$ and $60 \mathrm{~cm}$ with respect to ground area $15 \mathrm{~cm} \times 30 \mathrm{~cm}, K a V / L$ can be calculated in different value of $J_{\mathrm{a}} / G_{\mathrm{a}}$ by Eq. (9) as shown in Fig. 5. Accordingly, the required height of the filling

Table 3

Average atmospheric condition during summer time in Taiwan

\begin{tabular}{cllll}
\hline Year & Month & Average dry-bulb temperature $\left({ }^{\circ} \mathrm{C}\right)$ & Average humidity $(\%)$ & Average wet-bulb temperature $\left({ }^{\circ} \mathrm{C}\right)$ \\
\hline 2001 & 9 & 26.53 & 82.83 & 23.2 \\
& 8 & 30.1 & 71.69 & 25.8 \\
& 7 & 29.5 & 73.92 & 24.1 \\
2000 & 9 & 27.2 & 71.25 & 21.3 \\
& 8 & 28.4 & 78.88 & 24.2 \\
& 7 & 29.6 & 71.48 & 23.6 \\
\hline
\end{tabular}




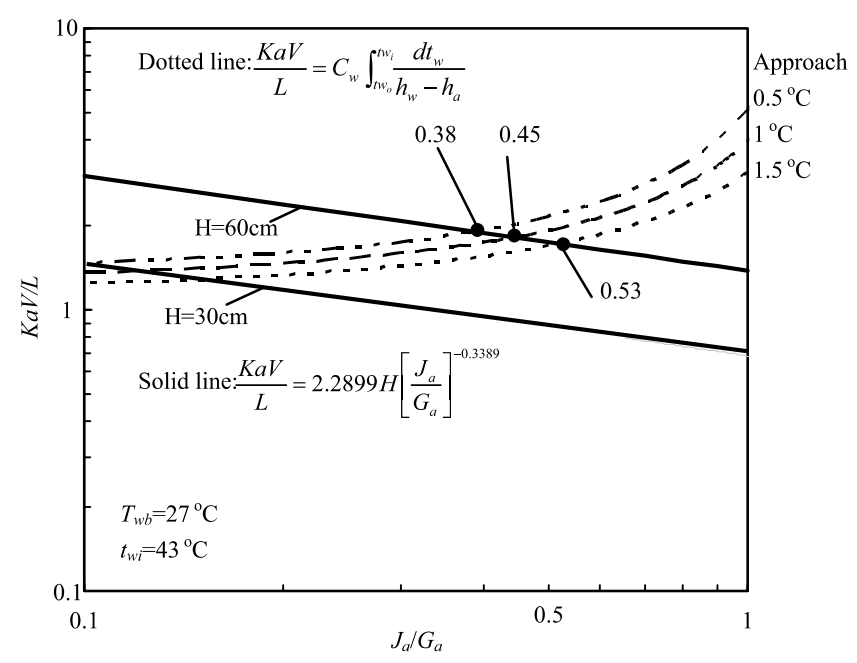

Fig. 5. Design $L_{\mathrm{a}} / G_{\mathrm{a}}$ and height of filling material.

material at the $J_{\mathrm{a}} / G_{\mathrm{a}}$ design value is found by the intersection of the representative curves from Eqs. (3) and (9).

It is seen that $60 \mathrm{~cm}$ height filling material has a proper $J_{\mathrm{a}} / G_{\mathrm{a}}$ value which ranges from 0.38 to 0.53 . In this case, the air velocity is around $3.13-4.37 \mathrm{~m} / \mathrm{s}$ at water flowrate $5 \mathrm{l} / \mathrm{min}$. For practical purposes, while keeping the air flowrate in constant, half the air velocity by doubling the volume of filling material into $0.6 \mathrm{~m}$ high, $0.6 \mathrm{~m}$ long, and $0.15 \mathrm{~m}$ wide could lower the fan power to about $85 \mathrm{~W}$. After that, the total power consumption of the cooling tower including pump power and fan power is approximately $98 \mathrm{~W}$.

The integral-type outdoor unit is $1 \mathrm{~m}$ high, $0.62 \mathrm{~m}$ long, $0.4 \mathrm{~m}$ wide and $4 \mathrm{~m}$ far from the indoor unit. The filling material size is $0.6 \mathrm{~m}$ high, $0.6 \mathrm{~m}$ long, $0.15 \mathrm{~m}$ wide.

\subsection{Instrument setup}

Twenty T-type thermocouples with an uncertainty of $\pm 0.7^{\circ} \mathrm{C}$ are mounted on the system and the signals are recorded using a hybrid recorder (YOKOGAWA DR130). Two pressure gages (REFCO) within $\pm 2.8 \%$ uncertainty are installed in the suction and discharge ports of the compressor for the pressure measurement and for converting to the condensing and evaporative temperatures using thermodynamic chart of R-22 (ASHRAE, 1993). The power consumptions of the compressor, fan and water pump are measured by power-meters which have $\pm 0.2 \%$ and $\pm 1 \%$ uncertainty, respectively. (Fan and water pump are measured by same power-meter.) Circulating water flow rate of condenser and evaporator are measured within $\pm 4 \%$ uncertainty. The cooling capacity and rejected heat of the Rankine-cycle is calculated by energy balance using the water flow rate and inlet and outlet water temperature difference.

The following uncertainties are obtained:

Total power $= \pm 1.02 \%$.

$\mathrm{COP}= \pm 5.37 \%$. 
The overall system is operated outdoors to simulate the real condition and each test takes about $30 \mathrm{~min}$ to assure a steady-state run. For $T_{\mathrm{c}}=42{ }^{\circ} \mathrm{C}$ and $T_{\mathrm{e}}=7{ }^{\circ} \mathrm{C}$, the optimum charge of R-22 is $1.32 \mathrm{~kg}$ and the capillary tube is $0.2 \mathrm{~m}$ long and inner diameter is $1.2 \mathrm{~mm}$.

\subsection{Test results and discussions}

During the test, the air wet-bulb temperature ranges from 20.5 to $27^{\circ} \mathrm{C}$, the relative humidity ranges from $70 \%$ to $90 \%$, air velocity ranges from 1.1 to $2.2 \mathrm{~m} / \mathrm{s}$, water flow rate ranges from 3.5 to $5.5 \mathrm{l} / \mathrm{min}$ and the inlet water temperature ranges from 38 to $45^{\circ} \mathrm{C}$.

The measured outlet water temperatures of cooling tower are compared with theoretical prediction by substituting the test conditions into Eqs. (3) and (9), as shown in Fig. 6. Although the operating wet-bulb temperature is $5^{\circ} \mathrm{C}$ lower than the test range of the fundamental cell unit, the theoretical data still coincides with the experimental data within $\pm 5 \%$ error.

As Fig. 7 shows, the present setup has COP $>3.45$ at $T_{\mathrm{e}}=7{ }^{\circ} \mathrm{C}$ and $T_{\mathrm{c}}<41.8^{\circ} \mathrm{C}$. If neglecting the power consumption of the fan and the water pump, COP will be larger than 3.45 at $T_{\mathrm{e}}=7^{\circ} \mathrm{C}$ and $T_{\mathrm{c}}<43.5^{\circ} \mathrm{C}$. This concludes the maximum condensing temperature for COP $\geqslant 3.45$. COP is defined as follows:

$$
\mathrm{COP}=\frac{\text { Cooling capacity }}{\text { Total power consumption }}
$$

The condensing temperature is commonly assumed to be a function of the inlet water temperature of condenser when applied to a constant water rate and constant temperature rise, as shown in Fig. 8. Six lines represented the condensing temperature with different inlet water temperature ranges from 23 to $28^{\circ} \mathrm{C}$ (because of the atmospheric condition, linear interpolation is used to

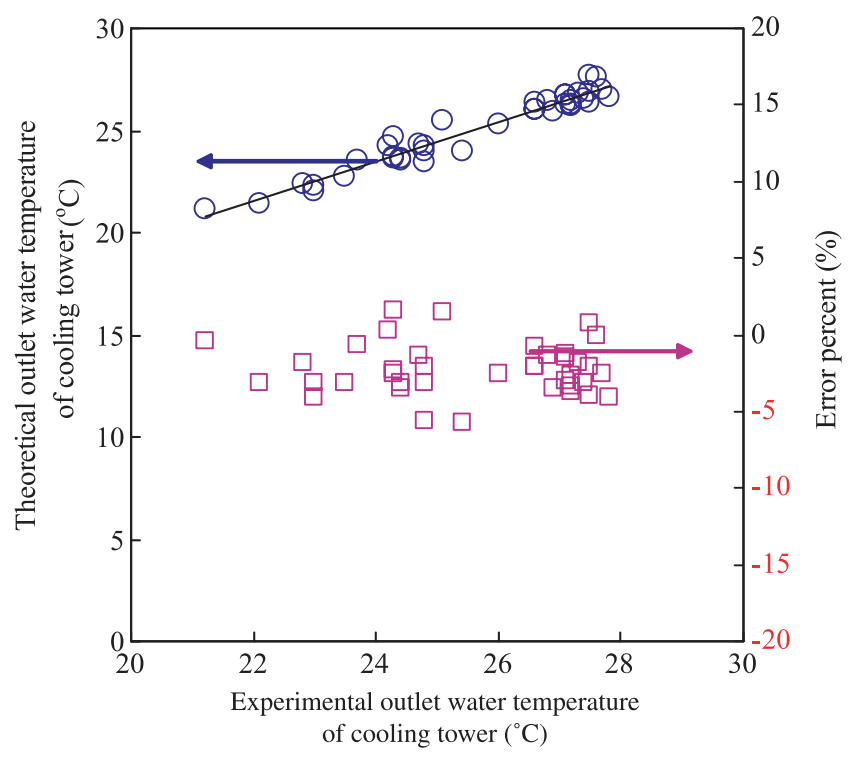

Fig. 6. Comparison of theoretical and experimental outlet water temperature of cooling tower. 


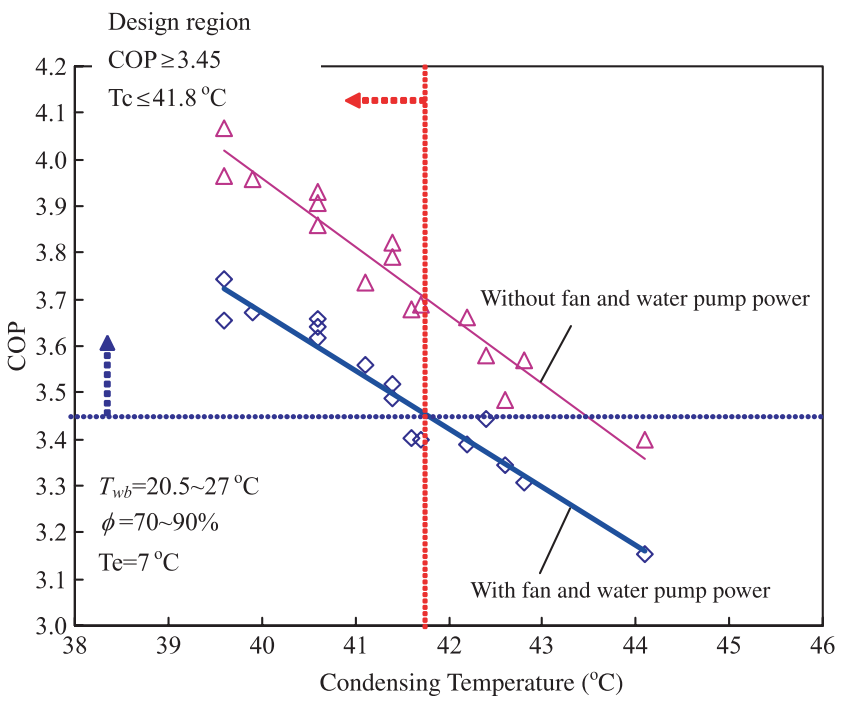

Fig. 7. COP versus $T_{\mathrm{c}}$ at $T_{\mathrm{e}}=7{ }^{\circ} \mathrm{C}$.

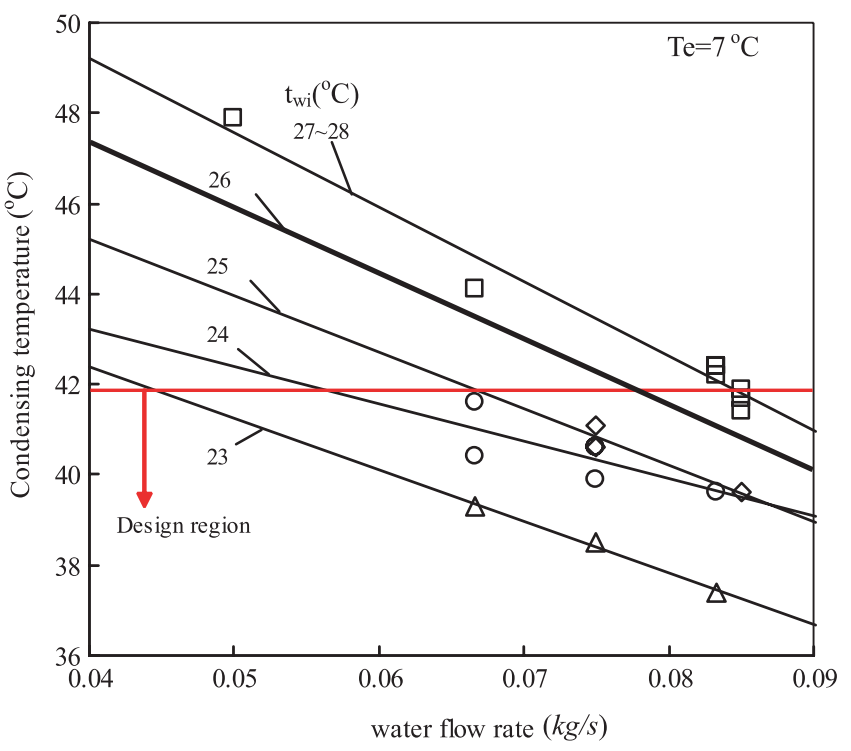

Fig. 8. Condensing temperature in different water flow rate and inlet temperature.

approximate $26^{\circ} \mathrm{C}$ ) and water flow rate ranges from 3 to $5.21 / \mathrm{min}$. This figure indicates that $T_{\mathrm{c}}$ tends to decrease with increasing water flow rate or decreasing inlet water temperature. On condition that, as shown in Fig. 8, the water flow rate and inlet water temperature are in the design region, the COP will be higher than 3.45 .

The inlet water temperature of the condenser which influences the COP of the system mostly depends on the wet-bulb temperature for a fixed $T_{\mathrm{e}}, L$, and $G$. According to ASHRAE test 


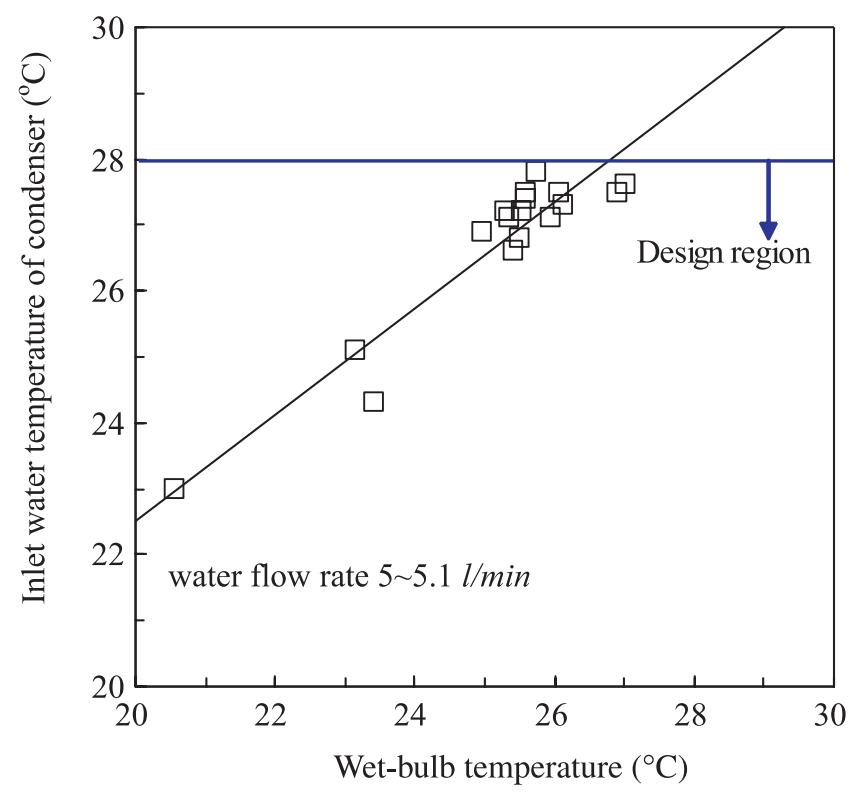

Fig. 9. The relation between the outlet water temperature of cooling tower and ambient wet-bulb temperature.

conditions for the cooling tests [16], the dry-bulb temperature should be $35 \pm 1.1^{\circ} \mathrm{C}$ and the wetbulb temperature should be $23.9 \pm 0.6^{\circ} \mathrm{C}$. In our worst case with higher wet-bulb temperature than ASHRAE test conditions, the inlet water temperature of condenser is $27.6^{\circ} \mathrm{C}$, $T_{\mathrm{c}}=41.8^{\circ} \mathrm{C}$ and $\mathrm{COP}=3.45$ when the wet-bulb temperature is $27^{\circ} \mathrm{C}$, dry-bulb temperature is $35^{\circ} \mathrm{C}, T_{\mathrm{e}}=7^{\circ} \mathrm{C}$, air velocity is $1.7 \mathrm{~m} / \mathrm{s}$ and water flow rate is $5.1 \mathrm{l} / \mathrm{min}$. That is, for the most atmospheric condition in Taiwan whose wet-bulb temperature is usually lower than $27^{\circ} \mathrm{C}$, we can obtain inlet water temperature lower than $27.6^{\circ} \mathrm{C}$. Hence, our goal to achieve $\mathrm{COP} \geqslant 3.45$ is verified, as shown in Fig. 9.

\subsection{Savings and profit payback analysis}

The energy savings and the profit payback due to the improvement of COP can be calculated. The economic analysis is based on the following conditions: cooling capacity $3.52 \mathrm{~kW}$, daily operation time $12 \mathrm{~h} /$ day, electricity price $0.1 \mathrm{USD} / \mathrm{kW} \mathrm{h}$. The water cost is neglected as compared to the electricity cost. Consequent results below indicate that energy savings per month is around 6.09 USD.

\begin{tabular}{lll}
\hline COP & Power $(\mathrm{kW})$ & Cost per month $(\$)$ \\
\hline 2.96 & 1.189 & 42.81 \\
3.45 & 1.020 & 36.72 \\
\hline
\end{tabular}

Retrofitting the system summed up to USD60, comprising the cooling tower, the circulating water pump and the connectors. Thereby, payback period is about 10 months. 


\section{Conclusions}

A high-efficiency split residential water-cooled air conditioner that utilizes cellulose pads as the filling material of the cooling tower was experimentally realized. Systematic optimizations of charge, capillary tube size were performed to maximize the benefit of the whole system. Our system improves the steady state COP from 2.96 to 3.45 under the following conditions: the wet-bulb temperature is $27^{\circ} \mathrm{C}$, dry-bulb temperature is $35^{\circ} \mathrm{C}$, air velocity is $1.7 \mathrm{~m} / \mathrm{s}$, water flow rate is $5.1 \mathrm{l} /$ min. Furthermore, the system COP can exceed 3.45 while the wet-bulb temperature is under $27^{\circ} \mathrm{C}$. The experimental investigation also verified the condensing temperature can be lowered to increase the system COP with only extra $98 \mathrm{~W}$ for cooling tower. The water-cooled condenser and cooling tower result in decreasing the power consumption of the compressor and consequently save enough energy to pay for the retrofit in 10 months.

\section{Acknowledgement}

The authors are grateful to their three reviewers who provided valuable comments and suggestions during the reviewing process.

\section{References}

[1] Y. Hwang, R. Radermacher, W. Kopko, An experimental evaluation of a residential-sized evaporatively cooled condenser, Int. J. Refrig. 24 (2001) 238-249.

[2] C.E. Groseclose, Cost comparison of air conditioning refrigerant condensing systems, Ref. Eng. June (1954) 54-58.

[3] C. Zimmerer, P. Gschwind, G. Gaiser, V. Kottke, Comparison of heat and mass transfer in different heat exchanger geometries with corrugated walls, Exp. Thermal Fluid Sci. 26 (2002) 269-273.

[4] M. Catalog, Evaporative Cooling Media, Fort Myers, FL, 1986.

[5] D.Y. Goswami, G.D. Mathur, S.M. Kulkarni, Experimental investigation of performance of a residential air conditioning system with an evaporatively cooled condenser, Trans. ASME 115 (1993) 206-211.

[6] D. Baker, Cooling Tower Performance, Chemical Publishing Co., New York, NY, 1980.

[7] J.R. Singham, The packing region, Heat Exchanger design handbook 3.12 (1983) 2.1-13.

[8] A.K.M. Mohiuddin, Knowledge base for the systematic design of wet cooling towers. Part I. Selection and tower characteristics, Int. J. Refrig. 19 (1) (1996) 43-51.

[9] A.K.M. Mohiuddin, Knowledge base for the systematic design of wet cooling towers. Part II. Fill and other design parameters, Int. J. Refrig. 19 (1) (1996) 52-66.

[10] H.R. Goshayshi, J.F. Missenden, The investigation of cooling tower packing in various arrangements, Appl. Thermal Eng. 20 (2000) 69-80.

[11] J.A. Dowdy, N.S. Karabash, Experimental determination of heat and mass transfer coefficients in rigid impregnated cellulose evaporative media, ASHRAE Trans. 93 (2) (1987) 382-395.

[12] D.Q. Kern, Process Heat Transfer, McGraw-Hill, New York, 1950.

[13] Cooling tower performance curves, Cooling Tower Institute, 1977.

[14] L.D. Bowman, Mean temperature difference in design, Trans. ASME 62 (1940) 284-294.

[15] T. Fujita, S. Tezuka, Calculations on thermal performance of mechanical draft cooling towers, ASHRAE Trans. 92 (1986) 274-287.

[16] American Society of Heating, Refrigerating, and Air-Conditioning Engineers, Inc., Methods of testing for seasonal efficiency of unitary air-conditioners and heat pumps (ASHRAE Standard ANSI/ASHRAE 116-1995), ASHRAE, 1995. 